\title{
USING THE AUDIOVISUAL TRANSLATION MINI-PROJECT FOR ADVERTISEMENT VIDEOS TO IMPROVE TRANSLATION SKILLS FOR SECOND-YEAR ENGLISH MAJORS AT THAI NGUYEN UNIVERSITY OF EDUCATION
}

\author{
Do Thi Ngoc Phuong*, Lo Thi Phuong Thao \\ $T N U$ - University of Education
}

\begin{abstract}
This study aimed to find out whether using Audiovisual Translation (AVT) of advertisement videos had effectiveness on improving translation skills for English majors at Thai Nguyen University of Education. There were 20 second-year English majors attending in the AVT miniproject. They had to do pre-test and post-test in order to examine if there was any improvement in their performance in their translation skill between the tests and answer an questionnaire for more details about their attitudes towards this method. The results from the pre-test and post-test have approved that there was a significant enhancement of the students' performance in translation skill after using AVT of advertisement videos. The figure from the questionnaire indicated that using AVT of advertisement videos helped the students gain more vocabulary, reduce their grammatical mistakes while writing English sentences and be more confident in translation than before.
\end{abstract}

Keywords: Audiovisual translation; translation; project; advertisement; video.

Received: 02/12/2019; Revised: 24/12/2019; Published: 21/02/2020

\section{SỬ DỤNG ĐỀ ÁN DỊCH NGHE NHİ̀ CHO VIDEO QUẢNG CÁO ĐỂ NÂNG ĊAO KĨ NĂNG DỊCH CHO SINH VIÊN CHUYỄN NGỮ NĂM HAI TRƯỜNG ĐẠI HỌC SƯ PHẠM - ĐẠI HỌC THÁI NGUYÊN}

\author{
Đỗ Thị Ngọc Phương*, Lô Thị Phương Thảo \\ Truòng Đại học Su phạm - ĐH Thái Nguyên
}

\section{TÓM TẮT}

Nghiên cứu này được thực hiện với mục đích tìm hiểu về hiệu quả của việc sử dụng hình thức dịch thuật nghe nhìn cho các video quảng cáo đối với việc cải thiện kĩ năng dịch thuật cho sinh viên tiếng Anh tại trường Đại học Sư phạm - Đại học Thái Nguyên. Với sự tham gia của 20 sinh viên chuyên tiếng Anh năm thứ 2 vào đề án dịch thuật nghe nhìn (AVT), sinh viên phải thực hiện các bài tiền kiểm và hậu kiểm để xác định được việc họ có cải thiện được kĩ năng dịch hay không. Đồng thời việc tiến hành thu thập dữ liệu bằng phiếu điều tra cũng cho thấy thái độ của người tham gia đối với đề án này. Kết quả từ tiền kiểm và hậu kiểm đã chứng minh được rằng sinh viên có cải thiện được kĩ năng dịch sau khi tham gia đề án AVT đối với các video quảng cáo. Số liệu từ phiếu điều tra cho thấy việc sử dụng đề án AVT đối với các video quảng cáo giúp sinh viên tăng cường được vốn từ vựng, giảm thiểu được các lỗi ngữ pháp khi viết câu bằng tiếng Anh, đồng thời giúp sinh viên tự tin hơn trong việc dịch thuật.

Từ khóa: Dịch thuật nghe nhìn; dịch thuật; đề án; quảng cáo; video.

Ngày nhận bài: 02/12/2019; Ngày hoàn thiện: 24/12/2019; Ngày đăng: 21/02/2020

\footnotetext{
* Corresponding author. Email: ngocphuong-do@dhsptn.edu.vn
}

DOI: $\underline{\text { https://doi.org/10.34238/tnu-jst.2020.03.2378 }}$ 


\section{Introduction}

These days, with the development of technology, utilizing videos in teaching and learning English has been risen as a new method. Audiovisual Translation (AVT) is one way to use the videos to facilitate the learning process and boost the translation skill for learners. According to Jennifer Lertola and Cristina Mariotti [1], AVT "offers the opportunity to maximize the benefits of translation by developing not only reading and writing but also listening and speaking skills". AVT can be distinguished into two main categories: revoicing and subtitling. Traditionally, it consists of the replacement of original dialogues for translation into another language [2], although, different language combinations are also possible. There are three types of the revoicing: muting the voice of the original actors (dubbing), speaking over the original voices (voice-over) or commenting on the scenes (free commentary). Dubbing was first used as an activity in class in a study of Duff [3], when students had to work in pairs to carry out different activities around adapting a drama play to a film. This practice continued years later with Kumai [4], as the activity improved the students' pronunciation, intonation and speed in oral expression and motivated them in learning process. Wagener [5] focused on the "consecutive interpretation of perfect synchronization" when dubbing and he worked on skills such as listening, vocabulary acquisition and independent learning.

Recent studies in relation to the use of AVT techniques in foreign language teaching and learning have shown various benefits of this method. In recent decades, several authors have declared that the use of video has a very positive and motivating effect, offering variety and entertainment together with its pedagogical function [6], [7], [8], [9]. Different authors indicated a variety of advantages in the use of AVT in foreign language teaching in their works [6], [10],
[11]: the boosting of self-esteem and confidence, the integration of the language in a natural way; attentive listening as an intrinsic element; the inclusion of verbal and non-verbal communicative elements; the wide variety of skills and learning areas that can be developed using a specific type of AVT, or several of them at the same time. Therefore, if students make good use of the audiovisual element in the learning process, they can comprehend the target language more effectively and develop other skills.

In this research, the researcher will investigate the use of audiovisual translation of advertisement videos, a specific type of videos, in order to improve the translation skills for second-year English majors at Thai Nguyen University of Education.

This research is expected to seek for the answers of these two questions:

1. To what extend does audiovisual translation of advertisement videos improve the second-year English majors' translation skill at Thai Nguyen University of Education?

2. What are the students' attitudes towards this method?

\section{Methodology}

\subsection{Participants}

The subjects of this study were the English major students from the second-year class (English K52) at Thai Nguyen University of Education. There were 20 female students at the age of 20-21 volunteered to take part in the study.

\subsection{Data collection instruments}

In this research, there are two data collection instruments to be used: tests and a questionnaire.

\subsection{Data collection procedures}

Before the mini-project, the researcher had to make sure that all the students who would use audiovisual translation of advertisement videos in practicing translation skill have devices with internet connection such as laptops or mobile phones. 
The mini-project was implemented to examine the effects of using audiovisual translation of advertisement videos in students' translation skills in blended learning environment. The subjects were 20 students in class English K52 at Thai Nguyen University of Education during an 8-week period. The researcher created a Facebook group including 20 participants, so that the researcher could illustrate the effectiveness of AVT of advertisement videos in students' translation skills by observing the procedure of the miniproject. The researcher instructed steps of using AVT of advertisement videos for the students in a face-to-face meeting, and then required the students to dub and subtitle advertisement in groups of 5 people at home. The chosen advertisement videos that were all in Vietnamese needed to be translated into English. The researcher selected the videos from simple and short in the beginning of the mini-project to more complex and longer ones in the end. The students were dubbing and subtitling 2 videos a week. There was also a meeting once a week in order to instruct the students and help them to find the ways to solve any problems that they had while doing the mini-project.

\section{Findings and discussions}

\subsection{Results from the tests}

The students' translation skill was measured in the pre-test and post-test to determine whether the AVT mini-project helped the students to improve their translation skill. The scores in the pre-test and post-test of 20 participants are displayed in Table 1.
Table 1. Students' scores in the pre-test and post-test

\begin{tabular}{cccc}
\hline Student & $\begin{array}{c}\text { Score in } \\
\text { pre-test }\end{array}$ & $\begin{array}{c}\text { Score in } \\
\text { post-test }\end{array}$ & $\begin{array}{c}\text { Gained } \\
\text { score }\end{array}$ \\
\hline Student 1 & 3.8 & 6.0 & 2.2 \\
Student 2 & 4.0 & 5.0 & 1.0 \\
Student 3 & 4.0 & 5.8 & 1.8 \\
Student 4 & 4.3 & 5.0 & 0.7 \\
Student 5 & 4.5 & 5.8 & 1.3 \\
Student 6 & 4.5 & 6.3 & 1.8 \\
Student 7 & 4.5 & 6.0 & 1.5 \\
Student 8 & 5.3 & 6.3 & 1.0 \\
Student 9 & 6.0 & 6.0 & 0.0 \\
Student 10 & 6.5 & 7.5 & 1.0 \\
Student 11 & 6.5 & 6.5 & 0.0 \\
Student 12 & 6.5 & 7.0 & 0.5 \\
Student 13 & 6.5 & 7.0 & 0.5 \\
Student 14 & 6.8 & 7.3 & 0.5 \\
Student 15 & 6.8 & 7.3 & 0.5 \\
Student 16 & 6.8 & 7.5 & 0.7 \\
Student 17 & 6.8 & 7.3 & 0.5 \\
Student 18 & 6.8 & 7.8 & 1.0 \\
Student 19 & 7.0 & 6.3 & -0.7 \\
Student 20 & 7.3 & 7.3 & 0.0 \\
\hline
\end{tabular}

The data from Table 1 reveal that there is a rise in the scores of the students since the gained scores are $95 \%$ positive numbers. In detail, 19 per 20 students' scores (95\% of the students) remained the same or increased (from 0.5 points to 2.2 points) in the post-test.

Table 2. Descriptive statistics for the students' performance in the pre-test and post-test

\begin{tabular}{|c|c|c|c|c|c|}
\hline \multicolumn{6}{|c|}{ Paired Samples Statistics } \\
\hline & & Mean & $\mathrm{N}$ & $\begin{array}{c}\text { Std. } \\
\text { Deviation }\end{array}$ & $\begin{array}{c}\text { Std. } \\
\text { Error } \\
\text { Mean }\end{array}$ \\
\hline \multirow{2}{*}{ Pair 1} & Pre-test & 5.7600 & 20 & 1.22921 & .27486 \\
\hline & Post-test & 6.5500 & 20 & .82876 & .18532 \\
\hline
\end{tabular}

Table 3. Results of the Paired Sample T-tests $(P<0.05$ level of significant)

\begin{tabular}{|c|c|c|c|c|c|c|c|c|c|}
\hline \multicolumn{10}{|c|}{ Paired Samples Test } \\
\hline & & \multicolumn{5}{|c|}{ Paired Differences } & \multirow{3}{*}{$\mathrm{t}$} & \multirow{3}{*}{$\mathrm{df}$} & \multirow{3}{*}{$\begin{array}{l}\text { Sig. (2- } \\
\text { tailed) }\end{array}$} \\
\hline & & \multirow[t]{2}{*}{ Mean } & \multirow[t]{2}{*}{$\begin{array}{c}\text { Std. } \\
\text { Deviation }\end{array}$} & \multirow[t]{2}{*}{$\begin{array}{l}\text { Std. Error } \\
\text { Mean }\end{array}$} & \multicolumn{2}{|c|}{$\begin{array}{l}95 \% \text { Confidence } \\
\text { Interval of the } \\
\text { Difference }\end{array}$} & & & \\
\hline & & & & & Lower & Upper & & & \\
\hline Pair 1 & $\begin{array}{l}\text { pretest - } \\
\text { posttest }\end{array}$ & -.79000 & .56279 & .12584 & -1.05340 & -.52660 & -6.278 & 19 & .000 \\
\hline
\end{tabular}


In order to draw the conclusion that it was the AVT mini-project that helped the students to improve their translation skills, the researcher used the Paired Sample T-tests in SPSS software. The participants' average scores in the pre-test and post-test were calculated and compared with each other.

As can be seen in Table 2, there was a significant increase in the average scores of the participants between the pre-test and posttest. In the pre-test, the students' average score was 5.76, and this figure rose to 6.55 in the post-test, after 8 -week-period of the miniproject. Moreover, the standard deviation in the post-test stood at 0.82876 , which was lower than the standard deviation in the pretest (1.22921). This means that the gap between students' scores in the post-test was smaller than the gap between students' scores in the pre-test. Therefore, not only the translation skill of the participants was improved but also the gap between their ability in translation was narrowed after participating in the AVT mini-project.

Alison Mackey \& Susan M. Gass [12] pointed out that "The accepted p-value for research in second language studies (and in other social sciences) is .05 . A p-value of .05 indicates that there is only a $5 \%$ probability that the research findings are due to chance, rather than to an actual relationship between or among variables" [12]. In other words, the significant value (p-value) of 0.05 is the probability in which the alternative hypothesis wrong is $5 \%$. In the contrary, it can be ensured that the alternative hypothesis has $95 \%$ confidence of being true.

Table 3 clearly shows the effectiveness of the AVT mini-project on students' translation skill since. The significant value, as being showed in the table, was smaller than 0.05 . This means that there was a significant difference between the scores in the pre-test and post-test. Consequently, the results of the project with the sig.value (p-value) is $0.000(<0.05)$ were reliable and the AVT mini-project did have positive effects on students' translation skill.
This finding implies there was strong evidence against the null hypothesis. Thus, the null hypothesis, which states there is no significant difference in the translation skill of the students before and after using AVT, is not supported in this study.

\subsection{Results from the questionnaire}

\subsubsection{The effectiveness of using AVT on students' vocabulary}

Figure 1. Students' attitudes towards the effectiveness of using AVT on vocabulary

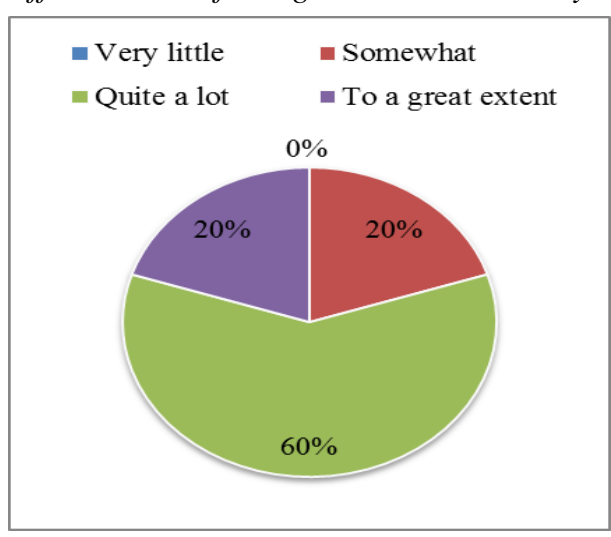

As can be seen in Figure 1, there are $60 \%$ of the students (12 students) agreed that their vocabulary has enhanced in size after using AVT of advertisement videos. The number of the participants who said that their vocabulary size has somewhat risen is $20 \%$ (4 students), and that is the same data for those who answered their vocabulary size has expanded to a great extent. These data show that using AVT had positive influence on the students' vocabulary as they gain more words after the project.

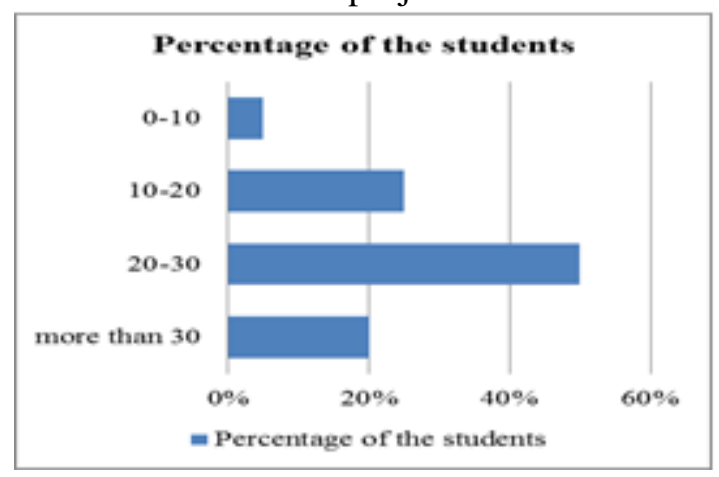

Figure 2. The number of words gained from using AVT of advertisement videos 
Figure 2 reveals the number of words gained that the students can estimate after using AVT of advertisement videos in 5 weeks. Half of the students believed they gained from 20 to 30 words from utilizing AVT of advertisement videos. Meanwhile, $25 \%$ of them thought that they gained from 10 to 20 words. The figure is lower in the number of students who estimated their vocabulary is added more than 30 words (20\% of the students), and there were only $5 \%$ of them chose the option " $0-10$ ". This result indicates that all the students have improved their vocabulary by using AVT of advertisement videos.

3.2.2. The effectiveness of using AVT on students' writing skill

One of the problems that the learners have while translating is the grammar, as each language has different grammatical rules. Figure 3 reveals if the students could improve their ability in writing a sentence in English more correct in terms of grammar.

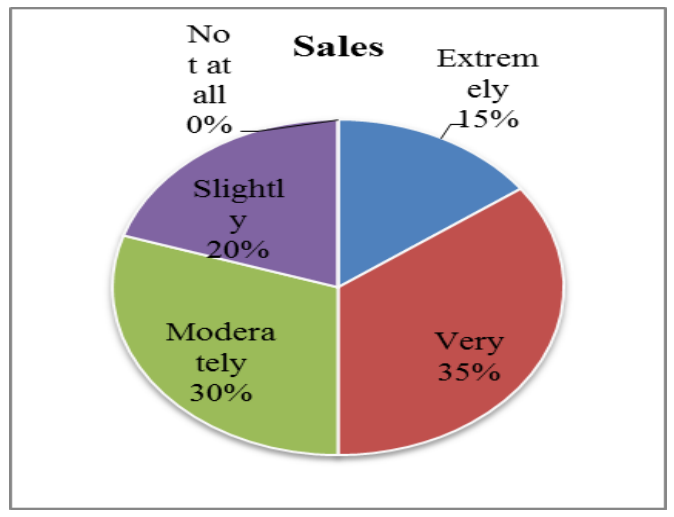

Figure 3. Students' confidence towards their improvement in the ability to write sentences in English with fewer grammatical mistakes than before

There was $20 \%$ of the students agreed that they felt slightly more confident than before while writing sentences in English in terms of grammar. That number rose to $30 \%$ in the option "moderately" for this question, as they thought they might still make grammatical mistakes sometimes. The highest figure was $35 \%$ for the option "very". These illustrations show that most of the students can write English sentences with fewer grammatical mistakes than before, that means most of them have improved their writing skill in English.

3.2.3. The effectiveness of using AVT on students' translation skill

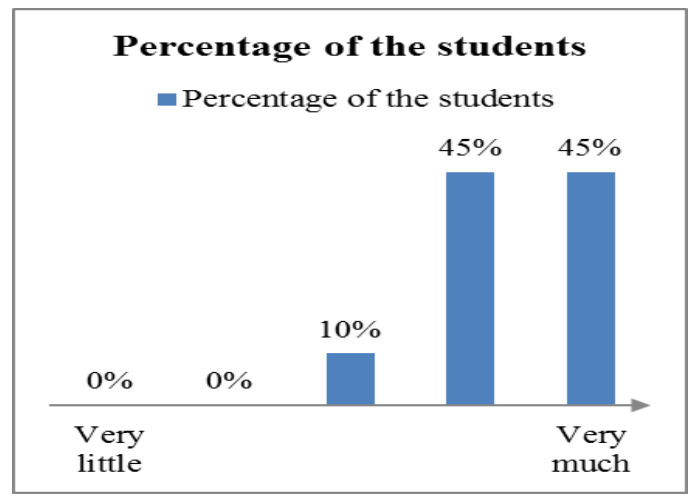

Figure 4. The students' attitudes towards the effectiveness of AVT mini-project on their translation skill

Figure 4 presents the percentages of the students' attitudes towards the effectiveness of AVT mini-project on their translation skill All of the students agreed that the project enhanced their translation skill. There were $10 \%$ of the participants who thought that using AVT of advertisement videos helps them to improve their translation skill moderately. The percentage of the students who believed that the project betters their translation skill quite a lot was $45 \%$, and that was also the data for those who agreed that their translation skill has been developed very much thanks to the AVT mini-project.

\subsubsection{The students' attitudes towards the AVT mini-project}

Figure 5 shows how much the students enjoy the AVT mini-project. It is noticeable that more than half of the students were very interested in using AVT of advertisement videos and $30 \%$ of the students showed that they were quite interested towards this method. Only three students $(15 \%$ of the participants) have moderate interest in the AVT mini-project. These data reveals that in general the students like this project. 


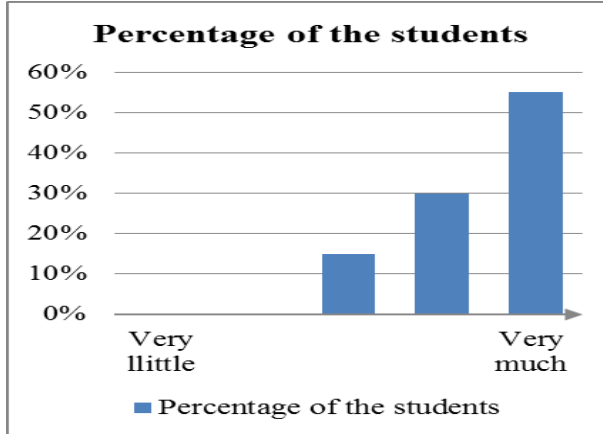

Figure 5. The students' attitudes towards the AVT mini-project

\section{Conclusion}

In this study, the effectiveness of the AVT mini-project on the students' translation skill was investigated. It has been found that using AVT of advertisement videos helped learners improve their translation performance in tests. The students translated Vietnamese advertisement videos into English by adding subtitles and voiceover in the videos, and they improved at a significant level from the pretest to the post-test scores.

The students' writing skill became better after the AVT mini-project. The students showed their improvement in the videos with AVT, as the researcher observed they wrote translated text more correctly in terms of grammar. Not only that, the participants recognized that they could translate Vietnamese text into English more smoothly and fluently, as they got used to the AVT of advertisement videos. They all agreed that their translation skill was enhanced thanks to the AVT method. All of the students show the positive attitudes towards the AVT mini-project and translation, as they acknowledged that they became more interested in both AVT and translation.

In addition, most of the participants thought that they learn more about how to edit video softwares in the computers like adding voices and subtitles into the videos. They also believed that applying AVT of advertisement videos is an effective way to introduce the domestic products to friends over the world.
Moreover, there was half of the students thought that the AVT project benefited their speaking skills as they could speak English more naturally and fluently than before; their teamwork skills were improved after the mini-project. Lastly, there was one student believed that AVT mini-project helped her to know how to choose the parallel English words with the Vietnamese ones while translating from Vietnamese to English after the project.

In conclusion, the AVT mini-project has satisfied the two research questions of the study. For the first question, translation skill of second-year English majors was proved to be improved significantly by using the AVT of advertisement videos during the 8-weekperiod project. For the second question, the students' attitudes towards the AVT method were positive as they shoed a huge interest towards AVT and translation.

\section{REFERENCES}

[1]. J. Lertola and C. Mariotti, "Reverse Dubbing and Subtitling: Raising Pragmatic Awareness in Italian English as a Second Language (ESL) Learners," The Journal of Specialised Translation, vol. 28, pp. 104-121, 2017.

[2]. F. Chaume, Cine y traducción. (Cinema and translation). Cátedra, Madrid, 2004.

[3]. A. Duff, Translation. Oxford University Press, Oxford, 1989.

[4]. W. N. Kumai, "Karaoke movies: Dubbing movies for pronunciation", posted on September 1996. [Online]. Available: http://www.jalt-publications.org/tlt/files/96/ sept/dub.html. [Accessed Nov. 12, 2018].

[5]. D. Wagener, "Promoting independent learning skills using video on digital laboratories," Computer Assisted Language Learning, vol. 19, pp. 279-286, 2006.

[6]. S. Brooke, "Video production in the foreign language classroom: Some practical ideas," The Internet TESL Journal, vol. 9, no. 10, Octorber 2003. [Online]. Available: http://iteslj.org/ Techniques/Brooke-Video.html. [Accessed Nov. 12, 2018].

[7]. S. Dubreil, "When students become directors: Redefining the role of the learner in the foreign language classroom," Best Practices for Using Technology to Teach and Learn Culture in the Foreign Language Classroom. Heinle \& Heinle, Boston, pp. 129-137, 2003. 
[8]. K. Biegel, "It is show time: Video production in the EFL classroom," Journal of the Japanese Association for Language Teaching, August 1998. [Online]. Available: http://jaltpub lications.org/tlt/articles/2346-its-showtime-video-production-efl-classroom. [Accessed Nov. 12, 2018].

[9]. M. Allan, Teaching English with Video. Longman, Essex, 1985.

[10]. M. Danan, "Dubbing projects for the language learner: a framework for integrating audiovisual translation into task-based instruction," Computer Assisted Language Learning, vol. 23, no. 5, pp. 441-456, 2010.

[11]. A. Maley and A. Duff, Drama Techniques: A Resource Book of Communication Activities for Language Teachers. Cambridge University Press, Cambridge, 2005.

[12]. A. Mackey and S. M. Gass, Second language research - Methodology and Design. Lawrence Erlbaum Associates Publishers, Mahwah, New Jersey London, pp. 265, 2007. 